\title{
TOWARDS A CURRICULUM FRAMEWORK FOR DEVELOPING TEACHERS' PERSONAL KNOWLEDGE MANAGEMENT COMPETENCIES ${ }^{1}$
}

\author{
Eric Cheng $^{2}$, Sonia Chan, Z. H. Wan, Vincent Hung, C. P. Lim, Y. C. Lai, T. M. Chan, C. \\ M. Tam
}

\begin{abstract}
This paper proposes a curriculum framework in pre-service teachers training program to develop Teachers' Personal Knowledge Management competency. Supporting the sustainable development of teachers as professionals in the knowledge society is a critical issue in teacher education. Personal knowledge management (PKM) is an intertwined macro-competency that involves cognitive, metacognitive, information, social and learning competencies. If PKM skills are taught, acquired and utilized in each discipline across the curriculum, pre-service teachers can organize, integrate and transform random pieces of information systematically to generate and apply them as personal knowledge. The framework provides pre-service teachers with different degree of opportunities to carry out instructional design, lesson implementation and reflection through e-learning and collaborative action research activities. A self-response questionnaire was conducted to evaluate the courses. Results show that an authentic learning environment could be created to develop pre-service teachers' PKM competencies for achieving effective learning.
\end{abstract}

Keywords: personal knowledge management competencies, e-learning, collaborative action research, instructional design competency, teaching education

\section{INTRODUCTION}

Recent education reform in Hong Kong highlights the development of student learning to learn skills for acquiring knowledge through various channels (Education Commission, 2000). To achieve this aim, teachers should learn how to teach their students learning to learn skills, and they are also expected to equip with this competency for learning pedagogical knowledge. The recent education reforms in Hong Kong (Education Commission, 2000) addressed this lifelong education issue by proposing a learning to learn slogan in the

\footnotetext{
${ }^{1}$ This research was financially supported by the Teaching Development Grant of The Hong Kong Institute of Education.

${ }^{2}$ The first author is associate professor of Department of Curriculum and Instruction of the Hong Kong Institute of Education. Correspondence can be directed to eckcheng@ied.edu.hk.
} 
policy document. Learning to learn is the basic skill for lifelong learning in a knowledge society (Hoskins \& Fredriksoon, 2008). Students should be well equipped with this skill to acquire new knowledge for effective learning. The policy suggests that teachers should develop student self-regulated competency for acquiring knowledge through various methods. To develop students with knowledge acquisition, application and sharing skills, teachers should also be equipped with the competency for knowledge acquisition, sharing, creation and presentation skills. The abilities to carry out these skills could be conceptualized as personnel knowledge management (PKM) competency.

PKM is as an intertwined macro-competency that involves cognitive, metacognitive, information, social and learning competencies. If PKM skills are taught, acquired and utilized in each discipline across the curriculum, pre-service teachers can organize and integrate information to provide strategies for transforming what might be random pieces of information into something that can be systematically applied and that expands their personal knowledge.

Developing learners with PKM competency is not simply a lifelong education issue, it is also an important teacher education issue in terms of sustaining a competitive human capital in the knowledge economy. Teacher development is viewed as an ongoing lifelong learning process as teachers strive to learn how to teach learner to learn how to learn (Cochran-Smith \& Lytle, 1999). Enhancing learners with learning competency for lifelong learning has become a core issue in teaching and teacher education. PKM is an innovative idea in teacher education. Developing a teacher education curriculum that could nurture preservice teacher sustainable professional competencies becomes a significant research agenda and a practical issue to be addressed in teacher education.

This study adopts Dorsey's PKM model to propose a curriculum framework for developing pre-service teachers' PKM competencies. The proposal PKM curriculum framework is based on empirical study of a group of pre-service teachers enrolled in bachelor of education program. A self-response questionnaire was conducted to collect data. The elements of PKM tools application, e-learning activities and collaborative action research are then developed and injected to the experiment courses. The courses provide pre-service teachers with different degree of opportunities to carry out instructional design, lesson implementation and reflection through e-learning and collaborative action research activities. The project tries to integrate elearning activities, PKM tools and collaborative action research in the proposed courses to develop student PKM skills. The integration of all these possibilities on the web in a way that the learners can select, individualize and customize the learning resources and services according to their needs and interests can support learners and teachers and enhance learning in general (Ebner, 2010). They could connect to both information and to communities with their own preferred PKM tools. An authentic learning environment could be created to help them to achieve effective learning, particularly instruction design. The results of the project will be adopted to formulate a PKM curriculum guide as a reference for teacher education curriculum development.

\section{LITERATURE REVIEW}

Recent literature has conjugated learning to learn competencies and information technologies closer to the domain of personal knowledge management (Dorsey, 2000). Frand \& Hixon (1999) proposed personal knowledge management (PKM) for undergraduate students as a means of contextualizing a more integrated learning experience as well as an alternative to the traditional narrow focus of a declared major. PKM provides a strategy for transforming what might be random pieces of information into something that can be systematically applied and that expands learner knowledge. Enhancing teacher PKM competency is probably an effective way to support them to convert information into their pedagogical knowledge. Research shows that there is a predictive relationship between PKM competency and learning effectiveness (Cheng, 2011; Wright, 2005; Tsui, 2002; \& Grundspenkis, 2007), in which learners can apply PKM competency to support their learning. PKM provides knowledge workers with both a common language and a common understanding of the intellectual and practical processes necessary for the acquisition of information and its subsequent transformation into knowledge. Teachers as knowledge workers could apply PKM to improve their instructional design capacities. The significance of developing PKM competency may contribute to human cognitive capabilities (Sheridan, 2008).

The increase in the amount and format of information do not necessarily make learners more informed or knowledgeable if a learner cannot manage and meld the accumulation of information through their daily experience and study to construct knowledge in a systematic fashion. This competency is referred by most literatures (Frand \& Hixon, 1999; Dorsey, 2000; Wright, 2005) as personal knowledge management (PKM) competency. Personal knowledge management can be conceptualized as an intertwined macro-competency. Wright (2005) develops a PKM model that links distinctive types of problem-solving activities with specific 
cognitive and metacognitive, information, social and learning competencies to develop knowledge workers PKM competency. As a knowledge management competency, PKM enables knowledge workers to apply a set of learning skills that are essential to lifelong learning for information processing, knowledge application and decision-making. As a cognitive and metacognitive competency, it enables knowledge workers to apply complex thinking skills to solve problems. As an information competency, it enables knowledge workers to link technology tools with a set of information skills, thus providing an intentionality that moves the focus from the technology more directly to the information. As a social competency, its underlying principles include enabling knowledge workers to understand others' ideas, develop and follow through on shared practices, build win-win relationships, and resolve conflicts. PKM integrates human cognitive and metacognitive competency (Sheridan, 2008), social competency (Wright, 2005; Pettenati \& Cigognini, 2009) and informational competency (Tsui, 2002).

Frand \& Hixon (1999) define PKM as a conceptual framework to organize and integrate important information such that it becomes part of an individual's personal knowledge base. After they had outlined five PKM techniques as searching, classifying, storing distributing, evaluating and integrating skills, Dorsey and colleagues (Avery, et. al., 2001) broadened the Frand \& Hixon PKM framework well beyond its formulation. Central to PKM, as clarified by Dorsey, are seven information skills which when exercised together are integral to effective knowledge work. These seven PKM skills are retrieving, evaluating, organizing, analyzing, presenting and securing information and collaboration for creating knowledge. The operationalized definitions of Dorsey (2000) PKM skills are as follows:

1. Retrieving skill is the ability of learners to retrieve information from relational databases, electronic library databases, websites, threaded discussion groups, recorded chats, and moderated and unmodulated lists.

2. Evaluating skill is the ability to make judgments on both the quality and relevance of information to be retrieved, organized, and analysed.

3. Organizing skill is the ability to make the information one's own by applying ordering and connecting principles that relate new information to old information.

4. Collaborating skill is the ability to understand others' ideas, develop and follow through on shared practices, build win-win relationships, and resolve conflicts between these underlying principles.

5. Analysing skill is the ability to extract meaning from data and convert information into knowledge.

6. Presenting skill is the ability to familiarize with the work of communications specialists, graphic designers, and editors.

7. Securing skill is the ability to develop and implement practices that help to ensure the confidentiality, integrity and actual existence of information.

Teachers are expected to be knowledgeable and up-to-date in subject knowledge, pedagogical knowledge and educational knowledge, all of which require an intensive on-going learning process. If their PKM skills are further developed, known and utilized in each discipline across the teacher education curriculum, they would come to understand how important holistic information skills and critical thinking skills are in processing, interpreting and synthesizing information and in producing and contributing knowledge in any content area. Actually, Dorsey emphasizes the importance of injecting PKM into undergraduate curriculum in order to bridge the gap between general education and other subject disciplines. PKM could serve as a framework for integrating general education and majors and as an approach to technology integration initiatives throughout the curriculum.

Recently, a few empirical teacher PKM studies have been conducted in school setting to verify PKM's impact on improving education. In Hong Kong, Cheng (2011) has conducted a survey to explore the relationship between PKM and knowledge acquisition of pre-service teachers. A four-factor PKM model, which consists of retrieving, organizing, analysing and collaboration skills, is empirically constructed. Pre-service teacher's PKM competency is identified to be a predictor for learning effectiveness. The result shows that PKM is a means for enhancing pre-service teacher's professional competency in learning instructional design, classroom management and assessment skills. Incorporation of PKM skills in teacher education curriculum is recommended to teacher education institutions for enhancing pre-service teacher PKM competency. This study developed a PKM curriculum guide and related e-learning activities to teacher educators but also provided empirical evidences to verify Dorsey's PKM model and to create dialogue with the international research communities in PKM and teacher education. 


\section{METHODOLOGY}

The training model of this study involves the development of participants' PKM skills by conducting cognitive, metacognitive, e-learning and collaborative learning activities. The e-learning activities of this study were delivered by action research approach. These e-learning activities of this project involved using Moodle and Google Doc to develop participants' PKM skills. The collaborative action research approach can develop teachers' learning competency and collaborative learning for knowledge creation. Action research is a form of self-reflective enquiry undertaken by participants in educational situations in order to improve the rationality and justice of their own educational practices, their understanding of these practices and the situations in which the practices are carried out (Kemmis, 1988). Pre-service teachers appreciate collaborative action learning and value opportunities for deliberation and reflection on experience (Eisner, 2002) as long as they feel confident speaking about their experiences of instructional design or acquisition of subject major knowledge.

Learning Study course was selected to implement the training model. It is a 39-hour course offered to preservice teachers of the bachelor of education programmes for developing their instructional design competencies. The course is seen as a type of cognitive and metacognitive training via action research in which pre-service teachers collaborate to create effective lessons and examine their practice (Fernandez, 2002; Lewis, 2002). Learning study course involves several groups of pre-service teachers to work on the design, implementation, testing, and improvement of one or several research lessons through practising their PKM skills. The focus of the research lesson lies in a specific teacher-generated problem, goal, or vision of pedagogical Cheng's (2011). During the course, pre-service teachers are taught the theories and practice of Learning Study and PKM tools in tutorials, and then work together in small subject groups through collaboration tools with support and guidance from the instructors to implement the Learning Study project. They have to retrieve, evaluate, organize the teaching materials in order to practice, which is carefully planned in collaboration with classmates, observed by other classmates, recorded for further analysis and reflection, and discussed by all classmates of the learning study course. They have to analyse student learning difficulties and to present their thinking throughout the course. This study adopted questionnaire survey to evaluate the student's PKM skills and the effectiveness of the PKM curriculum implementation, PKM Inventory was adopted to measure student PKM skills (see table). The instrument involves a six-point scale to measure students' perceptions of their PKM skills after taking the course. The participants of this study were 40 students from the bachelor of education programmes.

\section{RESULTS}

Table 1 illustrates the results of the post course survey. The reliability of each scale is higher than 0.7 , except the scale of "analysis skill" which is 0.567 . These reflect that the measurement of the instrument is reliable, but the one for "analysis skill" was not stable. All scale means of the PKM skills were higher than 4.4. These reflected that the participants tend to agree that they have equipped with each of the PKM skills. The seven skills are developed by the PKM curriculum framework embedded in the learning study course.

Table 1. Descriptive data of the post course survey

\begin{tabular}{|c|c|c|c|c|c|}
\hline & $\mathrm{N}=40$ & Mean & SD & $\alpha$ & S Mean \\
\hline \multirow[t]{3}{*}{ retrieval } & $\begin{array}{l}\text { It is easy for me to retrieve teaching material from the } \\
\text { internet. }\end{array}$ & 4.40 & .955 & \multirow[t]{3}{*}{0.700} & \multirow[t]{3}{*}{4.68} \\
\hline & I will never search through the internet without targets. & 4.68 & .859 & & \\
\hline & $\begin{array}{l}\text { I know how to retrieve the teaching material of my subject } \\
\text { effectively. }\end{array}$ & 4.75 & .809 & & \\
\hline \multirow[t]{3}{*}{ evaluate } & I will clarify my information needs & 4.88 & .757 & \multirow[t]{3}{*}{0.869} & \multirow[t]{3}{*}{4.46} \\
\hline & $\begin{array}{l}\text { Review the value and the index of stored information on a } \\
\text { regular basis. }\end{array}$ & 4.70 & .939 & & \\
\hline & $\begin{array}{l}\text { I always judge the quality and relevance of various pieces } \\
\text { of information to the problem at hand after retrieving from } \\
\text { somewhere. }\end{array}$ & 4.73 & .716 & & \\
\hline organize & $\begin{array}{l}\text { I use ordering and connecting principles that relate new } \\
\text { information to old information. }\end{array}$ & 4.65 & .893 & 0.846 & 4.75 \\
\hline
\end{tabular}




\begin{tabular}{|c|c|c|c|c|c|}
\hline & $\begin{array}{l}\text { I connect and organize information with electronic tools } \\
\text { such as directories and folders, databases, web pages, } \\
\text { and web portals. }\end{array}$ & 4.75 & .776 & & \\
\hline & I always synthesis and analysis information & 4.85 & .736 & & \\
\hline \multirow[t]{3}{*}{ analyse } & I can handle educational research data analysing & 5.10 & .672 & \multirow[t]{3}{*}{0.576} & \multirow[t]{3}{*}{5.00} \\
\hline & I can use MS Excel for statistical data analysis. & 5.03 & .660 & & \\
\hline & $\begin{array}{l}\text { I can interpret the hidden meaning of research } \\
\text { information }\end{array}$ & 4.88 & .686 & & \\
\hline \multirow[t]{3}{*}{ present } & $\begin{array}{l}\text { I always consider the purpose of the presentation that } \\
\text { related to audience for adjusting presenting. }\end{array}$ & 4.83 & .712 & \multirow[t]{3}{*}{0.758} & \multirow[t]{3}{*}{4.90} \\
\hline & $\begin{array}{l}\text { I use graphs and tables to illustrate some complex idea } \\
\text { and concepts. }\end{array}$ & 5.00 & .641 & & \\
\hline & $\begin{array}{l}\text { I will clarify the purpose of the presentation before my } \\
\text { presentation }\end{array}$ & 4.90 & .744 & & \\
\hline \multirow[t]{3}{*}{ secure } & I change my passwords regularly. & 4.35 & 1.099 & \multirow[t]{3}{*}{0.735} & \multirow[t]{3}{*}{4.40} \\
\hline & I backup my documents and files regularly. & 4.60 & 1.236 & & \\
\hline & $\begin{array}{l}\text { I am able to frame trade-offs regarding security in more } \\
\text { complex information sharing relationships with others. }\end{array}$ & 4.33 & .917 & & \\
\hline \multirow[t]{3}{*}{ collaborate } & $\begin{array}{l}\text { I can share relevant information to other team members } \\
\text { for completing the team tasks. }\end{array}$ & 4.90 & .778 & \multirow[t]{3}{*}{0.771} & \multirow[t]{3}{*}{4.87} \\
\hline & $\begin{array}{l}\text { I can conduct virtual meetings with other members via } \\
\text { communicative software. }\end{array}$ & 4.83 & .675 & & \\
\hline & $\begin{array}{l}\text { Sharing information with team members can enhance } \\
\text { team working effectiveness. }\end{array}$ & 4.90 & .672 & & \\
\hline
\end{tabular}

All the participants took part in the Learning Study groups, contributed to the planning and evaluation of the research lesson as needed to implement the two research lessons. They worked together in several small subject groups to understand others' ideas, develop and follow through on shared practices and build winwin relationships to implement Learning Study. During the course, they selected the topic for their teaching, set learning objectives for their students, and formulated pre-test and post-test papers. Each group retrieved information and teaching materials and to capture the knowledge relating to the selected topics from electronic library databases and websites. Through using the google applications, they retrieved relevant information, shared knowledge and collaborated with peers to co-constructed knowledge. They evaluated and judged the quality and relevance of information to be retrieved, organized, and analysed. Then they organized and summarized all the information and teaching materials by applying ordering and connecting principles that related new information to old information for designing lesson plans. They applied Google Docs for designing their lesson planning and Google PowerPoint for presenting their report. Their retrieving, evaluation and organizing skills were developed in this way. Participants analysed data from pre and posttest papers, and triangulated test scores with the teaching enactment through lesson observation or video record. This training exercise could help them to extract meaning from data and convert information into knowledge and their analysing skill was being developed. Finally, participants presented their findings and conclusions to their classmates and submitted their individual reflective report to the tutors. They applied graphic designers and editors to produce their PowerPoint presentation. Through presentation and report writing, participants could organize and externalize their tacit knowledge into explicate knowledge. Their ability to develop and implement practices that help to ensure the confidentiality, integrity and actual existence of information remain unchanged. The curriculum for the information secure skill needs future development.

The results of the study can be adopted to formulate a PKM curriculum guide as a reference for teacher 
education curriculum development. Course participants can demonstrate different PKM skills in completing the tasks and assignment through the following activities.

1. Grouping for collaboration: participants form groups and work on a group project. The aim of the group project should equip them with the subject knowledge and the Personal Knowledge Management (PKM) skills. The group activities should include creating group discussion forums with their instructors by using online tools such as Whatsapp, Moodle, Google Docs, etc. for group communication and collaboration.

2. Retrieving and evaluating relevant literature on subject knowledge: Each group should conduct literature review to capture the knowledge relating to the selected topics and then to organize and summarize their work for presentation.

3. Analysing and organizing literature: each group should conduct a midterm presentation to propose the idea of their group project which should include a summary of literature review. A mini group paper should be submitted in summarizing and analysing all the articles. The paper should include evidence of communication made through the online tools such as a screen capture of the member list in Whatsapp, or a folder taxonomy in the Google Docs.

4. Presenting idea for discussion: each group should share their works with other classmates, they should give a presentation and answer questions on the topic according to their findings and analysis. Besides Q\&A, each group are required to set the current forum available for public discussion (Moodle) by the class for a week. All classmates are required to comment on the presentation by all groups to ensure students have made reflection from comments raised from classmates and lecturer

5. Individual assignment: based on reflection made from the presentation, participants should submit a final assignment on their selected topic.

\section{CONCLUSION}

A comprehensive curriculum framework should integrate e-learning activities, PKM tools and collaborative action research in the proposed courses to develop student PKM skills. For example, injecting e-learning activities that require learners to utilize PKM tools like search/index tools, meta-search tools, information capturing and sharing tools, associative link tools and concept/mind mapping tools, email management, voice recognition, collaboration and synchronization tools. Mature e-learning tools like Wiki that allows learners to collect aggregate information collaboratively updated by worldwide users, and Google Docs that allow learners to edit documents collaboratively and instantly using word processing, spread sheeting, and presentation software. All these provide convenient and free platforms for learners to acquire collaborate and internalize knowledge that enables knowledge-construction, reflection and meta-cognition in the teacher education context.

\section{REFERENCE LIST}

Abdullah R. \& Talib A. M. (2012). Towards a personal knowledge Mmodel (PKM) in collaborative environment of school teachers' community. Computer and Information Science, 5(6), 50-57.

Avery, S, Brooks, R, Brown, J, Dorsey, P \& O'Conner, M 2001, 'Personal Knowledge Management: Framework for Integration and Partnerships', paper presented to Annual Conference of the Association of Small Computer Users in Education (ASCUE), Myrtle Beach, South Carolina, 10-14 June 2001.

Education Commission, HKSAR (2000). Review of education system-reform proposals: consultation document. Hong Kong: Government Printer.

Ebner, M., \& Taraghi, B. (2010). In Herrington J., Hunter B.(Eds.), Personal learning environment for higher education - A first prototype Chesapeake VA, Association for the Advancement of Computing in Education. (newly added)

Cheng, E. C. K. (2011). A study of the predictive effect of pre-service teacher personal knowledge. Journal of Knowledge Management Practice, 12 (3), online-journal.

Chai, C. S., Koh, J. H. L., \& Tsai, C. C. (2011). Exploring the factor structure of the constructs of technological, pedagogical, content knowledge (TPACK). Asia-Pacific Education Researcher, 20(3), 595-603.

Cochran-Smith, M., \& Lytle, S. L. (1999). Relationships of knowledge and practice: Teacher learning in 
community. In the series, Review of Research in Education, 24, 249-305. Washington, DC: American Educational Research Association.

Dorsey, P. A. (2000). Personal knowledge management: education framework for global business. Conference at the Knowledge Management, 17th Turkish National Information Systems Congress, Istanbul, September 2000. Decatur: Millikin University. Retrieved Oct 1, 2009, from: http://www.millikin.edu/pkm/pkm istanbul.html

Eisner, E. W. (2002). From episteme to phronesis to artistry in the study and improvement of teaching. Teaching \& Teacher Education, 18(4), 375-385.

Frand, J. \& Hixon, C. (1999). Personal knowledge management: Who, what, why, when, where, how? Working paper. Retrieved December 1, 1999, from http://www.anderson.ucla.edu/jason.frand/researcher/speeches/PKM.htm

Garner, S. (2010). Supporting the personal knowledge management of students with technology. Paper presented at the informing science and IT education conference (InSITE) 2010, Southern Italy. Retrieved September 30, 2010, from http://proceedings.informingscience.org/InSITE2010/InSITE10p237-246Garner764.pdf

Grundspenkis, J. (2007). Agent based approach for organization and personal knowledge modelling: knowledge management perspective. Journal of Intelligent Manufacturing 18 (4): 451-457.

Hauge, T. E. \& Wittek, L. (2003). Learning portfolio and ICT as cultural artefacts in teacher education. Paper presented to an invited symposium, functions of assessment in teacher education at the Biennial European Association for Research in Learning and Instruction Conference, Padua, Italy, August 2630th 2003.

Hoskins, B. \& Frediriksson, U. (2008). Learning to learn: What is it and can it be measured? Centre for Research in Lifelong learning (CRELL) report. JRC—Scientific and Technical Reports, European Commission. Retrieved January 15, 2009, from

http://crell.jrc.ec.europa.eu/L2L/learning\%20to\%20learn\%20what\%20is\%20it\%20and\%20can\%20it\%2 0be\%20measured_ver5.pdf

Kemmis, S. (1988). Action research. In J. P. Keeves (ed). Educational research methodology and measurement: nn international handbook, (pp.237-53). Pergamon: Oxford.

Mitchell, S. (2009). Personal easy wiki hosting, Scott Hanselman's blog, and snagging screens. Retrieved December 10, 2009, from http://msdn.microsoft.com/en-us/magazine/cc700339.aspx.

Pettenati, M. C., Cigognini, E., Mangione, J., Guerin, E. (2007). Using social software for personal knowledge management in formal online learning. Turkish Online Journal of Distance EducationTOJDE. 8(3), 52-65.

Pettenati, M.C. \& Cigognini, E. (2009). Designing e-activities to increase learning-to-learn abilities. eLearning Papers, 12. Retrieved September 30, 2010, form http://www.elearningeuropa.info/files/media/media18509.pdf.

Sheridan, W. (2008). How to think like a knowledge worker. United Nations Public Administration Network. Resource document. http://unpan1.un.org/intradoc/groups/public/documents/unpan/ unpan031277.pdf.

Tsui, E. (2002). Technologies for personal and peer-to-peer (P2P) knowledge management. A Computer Sciences Corporation Leading Edge Forum report. Retrieved September 30, 2010, from http://citeseerx.ist.psu.edu/viewdoc/summary?doi=10.1.1.84.9689 1-53.

Wright, K. (2005). Personal knowledge management: supporting individual knowledge worker performance. Knowledge Management Research \& Practice, 3(3), 156-165.

Yeh, Y. C., Huang, T. H. Huang, and Hsiao C. C. (2012). An evaluation of core competence on knowledge management for elementary schools' teachers: a case study of remote rural area in Taiwan. Journal of Education and Vocational Research, 3(9), 303-312.

Zuber-Skerritt, O. (2005). A model of values and actions for personal knowledge management. Journal of Workplace Learning, 17(1/2), 49-64.

Zhao (2009) Teachers' personal knowledge management in China based Web 2.0 technology, in Miltiadis D. Lytras, Patricia Ordóñez de Pablos, Social Web Evolution: Integrating Semantic Applications and Web 2.0 Technologies, IGI :USA. 